\title{
CRITICAL DISCOURSE ANALYSIS ON KOMPAS DAILY NEWSPAPER REPORT ON PROFITEERING THROUGH THE NAMES OF PRESIDENT JOKOWI AND VICE PRESIDENT JUSUF KALLA
}

\author{
Marianus Fergilus Lede Todo, I Wayan Budiarta \\ University of Warmadewa \\ marianus.todo@gmail.com
}

$\begin{array}{lll}\text { Received: } 03-05-2017 & \text { Revised: } 16-10-2017 & \text { Accepted: 03-02-2018 }\end{array}$

\begin{abstract}
The objectives of this study were to (1) describe the structure of Kompas daily news texts about the profiteering of the names of Indonesian President Joko Widodo and Vice President Jusuf Kalla, (2) to explain the mental consciousness of journalists forming daily Kompas texts about profiteering the names of Indonesian President Joko Widodo and Vice President Jusuf Kalla, and (3) to explain the social context influencing the formation of Kompas daily texts about the profiteering of President Joko Widodo and Vice President Jusuf Kalla. The method used in this research was qualitative research method. The data used in this research was news texts from Kompas daily newspaper, which reported about the case of profiteering of the name of Indonesian President and Vice President. Data collection method employed was literature study. The data in was analyzed with the orientation of analytic descriptive method. The results of data analysis showed that at the level of macro structure, superstructure, and micro structure, the global meaning of discourse developed in the news is about the settlement of cases of profiteering of the President and Vice President. The act of profiteering on the name of Indonesian President and Vice President was judged only to delegitimize the authority of the President and Vice President and state institutions. Meanwhile, the journalist's mental awareness that formed the Kompas daily news texts includes role schemes and event schemes. While the social context that influenced the formation of the discourse of naming consists of power and access. The ideology reflected in Kompas daily news texts is Pancasila.
\end{abstract}

Keywords: text structure, mental awareness of journalist, social context, Pancasila

\section{INTRODUCTION}

As an information reference, mass media, both print and electronic, must be recognized has become one of the most decisive factor for human life. The advancement of custom and culture as well as development of Indonesian language is also strongly influenced by the role of media (Mbete, 2013). Normally media appear in both verbal and nonverbal languages, but the language used is not seen in enclosed spaces. According to (Sobur, 2001), media content is the result of reality construction with language as its basic device. Language in the mass media is not just a communication tool to convey facts, information, opinions, or describe reality, but also determine the image or a specific image that would be implanted to the audience.

Media as a discourse will also discuss the language used, the underlying knowledge, and forms of interests and power operating beyond the language. The study of the media will thus reveal also the ideology that shapes it, which in turn will affect the language (style, expression, vocabulary, and sign) used, and the knowledge (justice, truth, and reality) it produces (Piliang, 2004).

Almost all media claim to be objective, such claims, according to (Rokhman, Surahmat 2016), need to be questioned continuously. Objectivity will remain difficult to realize because the media is managed by humans who have ideas, value systems, and perceptions. This value system influences its perspective when viewing information. This value system is also very influential on the framing of the news it produces. Thus, the media is no longer seen as a free and neutral channel, in which all parties can

\section{express their positions and views freely}

Therefore, to understand the use of language in the mass media is critical paradigm. In a critical paradigm, language is regarded as a representation that plays a role in shaping certain subjects, certain themes of discourse, and strategies in them. Therefore, discourse analysis is used to dismantle the power that exists in every language process (Badara, 2012).

This study examines the use of language in Kompas newspapers. The analysis was conducted on the daily Kompas news texts about the profiteering of President Joko Widodo and Vice President Jusuf Kalla in the case of PT. Freeport Indonesia, which involves the Chairman of the House of Representatives (DPR) Setya Novanto. As commonly known, the case of profiteering or popularly known as the "Papa Minta Saham" case is a national issue warmly discussed by the mass media from November to December 2015.

Case extension contract PT. Freeport Indonesia entered a new phase when Ministry of Energy and Mineral Resources (hereinafter abbreviated MEMR) Sudirman Said officially reported the case of professorship of the President and Vice President to the Court of Appeal on November 16, 2015 on the alleged violation of the code of ethics (Sugiya, Aritasius, Ratnawati, 2016). The trial code of ethics was also scheduled to clarify the case of profiteering, which culminated with the resignation letter Setya Novanto from jabatanya as the Speaker of the House.

In Kompas daily news, the language tendency used is evocative and imperative. Evokatif means 
wanting an emotional response from audiences readers. While the imperative means to command or direct in order to control others. That is, the language used can direct the reader's perception. This is reflected, either from the use of words, phrases or sentences contained in the news texts

In addition, Kompas also holds the control of the public discourse to direct the reader's perception to denounce the act of profiteering on the names of the President and Vice President. Control over public discourse is seen in part from granting more access to governments, legislative supporters of government parties, or interfaith figures to respond to cases of profiteering. The access provided by Kompas is suspected by the underlying political context and ideological similarity.

\section{A. CONCEPT}

According to (Van Dijk, 1995), critical discourse analysis is a kind of research on discourse, especially analyzing how power misuse, dominance, inequality are created and reproduced through text or conversation in social and political contexts. Furthermore, Fairclough and Wodak (in van Dijk, 1997: 258) explain that discourse practice may reflect ideology: Critical discourse analysis can produce unequal power relationships between social classes, men and women, majority groups, and minorities. Critical discourse analysis seeks to examine how the language used to know the imbalance of power in society occurs. Critical discourse analysis seeks to investigate how language use by social groups fights each other and seeks to win the ideological battle.

\section{CONCEPT OF TEXT AND CONTEXT}

The concept of the text is expressed by (Halliday, M A K., Hasan, 1992) who stated that the text is a language in use - a language that is performing certain tasks in the context of a situation. The most important thing about the nature of the text is that although it is written it appears to consist of words and sentences, but it actually consists of meanings. The text must be encoded in something to be communicated; but as something independent, the text is essentially a unit of meaning. In order to understand the text, an understanding of context is required. This means the text will always be integrated into the context, both in its formation and in the process of understanding it. According to Guy Cook (in Eriyanto, 2001: 9), there are three things that need to be understood in terms of discourse, namely text, context, and discourse. Text is all the forms of language. Context includes all situations and things that are outside the text affects the use of the language. Discourse here, then interpreted as text and context together.

\section{CONCEPT OF NEWS}

According to Kamus Besar Bahasa Indonesia (KBBI) "Indonesian Big Dictionary", news is a story or description of events or warm events, reports, and notices. Thus it can be concluded that the news is an actual report on the events or important events that occur in human life.

\section{CONCEPT OF NEWSPAPER}

(Suryawati, 2011) explains that the newspaper is a medium of communication that contains actual information from various aspects of life such as: political, economic, social, criminal, cultural, art, sport, abroad, domestic, and so on. Meanwhile, newspapers are printed sheets containing reports that take place in the community with features such as: periodic public, general, actual content, about anything in the world contains values for the readers to know. Thus it can be concluded that the newspaper is the actual information that contains reports that occur in the community periodically, whether in the social, political, economic, cultural, and so on.

\section{B. THEORETICAL FRAMEWORK}

The theoretical framework developed by van Dijk is called the socio-cognitive approach or model. Discourse is described as having three interrelated dimensions: text, social cognition, and social context.

\section{TEXT STRUCTURE}

Van Dijk sees text as a structured entity. The approach he proposes is based on three levels of text structure, namely: macrostructure, superstructure, and microstructure.

Macro structure is the global or general meaning of a text that can be observed by looking at a topic or theme that put forward in a discourse. (Van Dijk, 1985) explains "The topic as the macro structure of a discourse organizes what is most important in a text, because the topic describes the core idea and shows the dominant concept of a text. Practically, news topics are reflected through headlines and lead terraces. As noted by (Van Dijk, 1985) "headline and lead may be used as an expedient signal to make effective guesses about the most important information of the text."

Meanwhile, superstructure is a global form of discourse. The importance of a superstructure or schematic is a media strategy to support a particular topic to be conveyed by composing sections in specific sequences. The elements analyzed in the superstructure include summary and news stories.

Firstly, a summary - it is expressing an important topic or theme of a text. Summary in the context of news is characterized by two elements, namely title and news terrace. Secondly, news stories refer to the content of the news as a whole. Elements analyzed in news stories, namely: (1) main events - organizing all information about the actual events rose in the news; (2) background, which is contextual and historical. Context includes all information in news reports about the actual situation of news. The context is marked with a marker during, at the same time, moment, or similar marker. While historical is an event that has occurred in the long span of time such as: a few 
months, or several years earlier; (3) the consequences - related to the impact that may be caused by a given event or event. One of the standards of the subcategory of consequences is verbal reactions of the figures cited in the news; and (4) comments are divided into two parts, namely expectations and evaluation. Van Dijk (1988a: 56 in Main, 2015: 46) explains that hope as a possible cause or to be the result of the events being preached. In other words, expectations contain predictions or diarrhea occurring in the future, while the evaluation is the view or opinion of the text maker about the event being reported.

While the micro structure is a discourse meaning that can be observed from the choice of words, sentences, and styles used. The use of certain words, sentences, propositions, styles or rhetoric by the media is not seen as a way of communicating, but judged as communicating politics - a way of influencing public opinion, creating support and strengthening legitimacy. Things observed in the microstructure include semantics, syntax, stylism, and rhetorical. First is semantics. In the van Dijk scheme, semantics is categorized as local meaning, meaning that arises from interrelated relationship and the relationship between propositions that construct a particular meaning in a text building. The elements studied in semantic, ie; (1) details - related to the control of the information displayed in the news text; (2) intent - see information that benefits communicators will be described explicitly and clearly. Conversely, the adverse information will be described disguised, implicit, and concealed; (3) presupposition. The conditional element is a statement used to support the meaning of a text. The conditional element is almost similar to reasoning, which is used to provide a rational basis so that the text presented by the communicator seems correct and convincing (Sobur, 2012: 79).

According to, the form of a sentence is a syntactical facet that relates to logical thinking, namely the principle of causality. This form of sentence is not just a question of grammatical truth, but it determines the meaning shaped by the order of sentences; (2) conditional coherence - the usage of the clause as explanatory, which is indicated by the conjunction 'which' or 'where'; (3) the distinguishing coherence relates to the statement of how two events or facts are to be distinguished. Two events are made as if contrary to using this coherence pattern; and (4) pronouns. The pronoun element is strategically used to create an imaginative community. The pronoun element is marked with the use of 'me', 'us', 'us', 'or' them.

Third, is stylistic. The center of attention of stylists is the style that a person uses to express his intentions by using language as a means. The elements analyzed are the use of lexicon or diction. And fourth is rhetorical. Rhetorical has a persuasive function and is closely related to how the message is to be conveyed. One form of rhetorical strategy is the use of metaphors. Metaphors are used strategically to reinforce the central message of a preaching.

\section{SOCIAL COGNITION}

The second dimension in van Dijk model framework is social cognition. The cognitive approach is based on the perception that the text has no meaning, but is given by the language user. Each text is basically produced through a certain awareness and knowledge of an event. How the event is understood and understood is based on the scheme. Scheme, as a model is closely related to social representation that is how views and beliefs develop in society. Several schemes/models in relation to the analysis of social cognition. First is the Person Schemas. This scheme illustrates how one looks at others. Second is the Role Schemas. This scheme deals with how someone views and describes the role and position one occupies in a society. Third is the Event Schemas. This scheme illustrates how a person perceives an event is related to other events.

\section{SOCIAL CONTEXT}

The third dimension of van Dijk analysis is the social context. In relation to this social context, there are two important aspects studied: power and access. First is power. Van Dijk defines power as ownership by a group to control other groups. In addition to direct and physical control, power according to van Dijk is also understood in the form of persuasive: one's actions indirectly control by influencing mental states such as beliefs, attitudes and knowledge. Second is access. In this case how access between each group influences media media discourse. Those with access have a greater chance to have access to the media. Greater access not only provides an opportunity to control audience awareness, but also influences the topic and content of the discourse.

\section{DISCUSSION}

In this section of discussion, the exposure of data analysis begins by examining the overall macro structure, superstructure and microstructure of six daily Kompas news texts used as data sources. Next, analyze at the level of social cognition and social context. The six daily news of Compass are used as data sources, namely: (1) "Buka Nama Pencatut 'Open the Name of Profiteer'" (Saturday, 14/11/2015), (2) "Publik Geram Ingin Dituntaskan" 'Public Furiosity is Needs to Relieved'" (Jumat, 20/11/2015 edition) (3) "Presiden Luapkan Kemarahan 'Presdient Bursting into anger"' (4) "MKD Tentukan Kewibawaan DPR 'Honorary Council of the Court Determines the Authority of the the House of Representative'" (Wednesday edition, (9/12/2015), (5) "Dengarkan Suara Rakyat "Listen to the People's Voice'" (3) edition Wednesday, 16/12/2015), and (6) "Kemenangan Suara Rakyat 'Victory of the People's Voice'" (Thursday edition, 17/12/2015).

\section{A. MACRO STRUCTURE OF TEXT KOMPAS DAILY NEWS}


As described in previous theoretical descriptions, an analysis of the macro structure to understand the global meaning of an observed text through a news topic. From the analysis of macro structure, the global meaning of the whole daily Kompas news texts is to demand the settlement of the case of profiteering of the names of President Joko Widodo and Vice President Jusuf Kalla. The global meaning is implied through the daily news topics of Kompas. The news topics from the whole news texts are as follows:

1) The importance of unlocking the identity of the perpetrators of profiteering on the name of the President and Vice President.

2) Public outrage for the settlement of alleged cases of profiteering on the name of President and Vice President.

3) President's anger and public condemnation responded to a closed court proceeding at the Honorary Council of the Court (hereinafter abbreviated as HCC).

4) The authority of the People's Legislative Assembly is determined by the decision of the HCC.

5) The decision of HCC expected to listen to the aspirations of the people.

6) The resignation of Setya Novanto from his position as Speaker of the House is a victory of the people.

\section{B. SUPER STRUCTURE OF KOMPAS DAILY NEWS TEXTS}

Analysis at the superstructure level begins by looking at the news summary; title and news terrace. Further, analysis at the level of news stories such as: main events, context, historical, verbal reactions, expectations and evaluation. The summary of news that reflects the essence of the six daily news Kompas as follows:

1) Expectation of $\mathrm{HCC}$ is that the Minister of Energy and Mineral Resources Sudirman Said to inform the identity of members of the House of Representatives who did profiteering the name of President and Vice President.

2) Various petitions and expressions of public disappointment, which requires a concrete solution of the case of profiteering on the name of the President and Vice President.

3) President's anger as a form of emotional expression when questioned related to the trial process in HCC related to allege profiteering.

4) The authority of the People's Legislative Assembly is determined by the decision of the HCC.

5) The public taps the conscience of the HCC in order to make decisions in the code of ethics always think clearly and uphold the common sense.

6) Setya Novanto's resignation from the post of Speaker of the House was a victory of the people.

Furthermore, the analysis at the level of news stories begins with seeing the main events contained in six daily news texts Kompas. As previously described, the main event organizes all information about the actual events raised in the news. The following are the main events that are reflected in Kompas daily news texts:

1) Request from HCC to the MEMR Sudirman Said to open the identity of the perpetrators profiteering the name of President and Vice President.

2) There is uncertainty from HCC to resolve the alleged cases of profiteering on the name of the President and Vice President.

3) The President's anger over the trial process to examine the Speaker of the House of Representatives Setya Novanto as being united by the $\mathrm{HCC}$ is done in private.

4) The decision of the HCC related to the case of alleged violation of code of ethics involving the Chairman of the House Setya Novanto greatly determines the authority of the House of Representatives.

5) The possibility of a HCC decision regarding the alleged violation of the code of ethics. Whether the HCC decides whether there is an ethical violation or otherwise does not decide ethics violation against the Speaker of the House Setya Novanto.

6) Setya Novanto's resignation letter from his position as Speaker of the House.

In addition to the main events, in Kompas daily news texts there are also various elements of the news context - including all information in news reports about the actual situation of news. Below is presented some elements of news context contained in the Kompas daily news texts:

1) When contacted separately, Nurul Arifin who is Special Staff Speaker of the House Setya Novanto refused to comment on this issue (news 1, paragraph 9).

2) However, to date, the HCC has not yet determined when it will settle the case (News 2 , sentence 1, paragraph 2).

3) Ahead of and during the examination of Novanto, there appeared a number of related reports of the existence of a number of parties who agreed to secure Novanto in this case (news 3, sentence 1, paragraph 13).

4) During the lead of Novanto, in terms of achieving the legislation target, the House of Representatives has only approved two bills in the 2015 Priority National Legislation Program (Prolegnas) list and one Bill outside of priority Prolegnas (news 6, sentence 2, paragraph 15).

The current marker on the data (1) provides information related to the rejection of Nurul Arifin as Special Staff of the Speaker of the House of Representatives Setya Novanto when questioned by journalists. Through the context of the news, it gives clues to the readers about the identity of politicians 
in question by the MEMR Sudirman, namely Speaker of the House Setya Novanto. In the data (2), the news context is marked through phrases to date, indicating the time statement that in the preceding period, since the reported case of alleged profiteering of the President and Vice President by the Minister of Energy and Mineral Resources Sudirman Said, there is no certainty from the HCC to follow up or resolve the case of profiteering the name. In the data (3) the context of the news is known through the marker as long as it also gives confirmation that in the preceding period (although not explicitly explained in the news text), there has been a planned effort by some political parties in the legislature to secure the case of President's name Vice President. Meanwhile, the marker of during on the data (4), Kompas daily News attempts to invite readers to provide an assessment of the performance of the legislative work during the lead by Setya Novanto.

In addition to the elements of the news context, in Kompas daily news texts there are also various historical elements, which describe events that have occurred over long periods of time. One of the historical elements contained in the Kompas daily news texts is:

5) This problem stuck out the first time in the event Satu Meja in Kompas TV, November $3^{\text {rd }}$. Sudirman said there were some very powerful political figures who sold the names of the President and Vice President to ask for a power plant project in Timika and an empty stake from Freeport (news 1, paragraph 10).

The historical elements in the data (5) provide the reader with information central to the initial siting of the alleged case of profiling of the President and Vice President to the public sphere. Thus, the reader has been given the central information that the initial revelation of the case was started at the Satu Meja show on Kompas TV on November 3rd.

In addition to the historical elements, in six Kompas daily news texts there are also various verbal reactions submitted by public figures. The following describes some verbal reactions from the President, Vice President, and representatives of one of the religious leaders quoted in Kompas daily news:

6) "This case can be dangerous because investor confidence is lost, whereas Indonesia is inviting many investors. If the case is not explained, people no longer trust the government. If you do not believe in the President and Vice President, this country is damaged because its leader is considered corruption, "he said (news 2, paragraph 15).

7) "The process in daily should be respected, "said the President (news 3, paragraph 3)." But ... but, it should not be a state institution to mess with. The state institution can be a presidency or other state institution, "continued the President (news 3, paragraph 4). The President added, "I'm nothing but a crazy President, sarap, President Koppig (stubborn) is okay. But if it concerns the authority of profiteering (the name of the President) to ask for an 11 percent stake, this is what I do not want, do not want to. It's a matter of propriety. The virtue of morality and that is the question of the authority of the state. Enough. "(News 3, paragraph 5).

8) "If the $\mathrm{HCC}$ and the House of Representatives are still willing to be respected by the people and still listen to the people, give severe sanctions to Novanto because he has committed severe violations, "said Chairman of Muhammadiyah Central Executive Ahmad Syafii Marif (news 4, paragraph 2).

Verbal reactions to data (6-8) have high news value because they cover the aspects of the impact (consequence). This shows the character of the information presented, including large and has a broad influence on the audience. Considering, the sources cited in the news are the President, Vice President and one of Islamic religious leaders from the Muhammadiyah organization. Data (6) is a verbal reaction in the form of a direct quote delivered by Vice President Jusuf Kalla. The substance emphasized from the verbal reaction is the alleged profiteering of the name will give a bad impact on the business world, because it can lose the confidence of investors who will invest in Indonesia. In addition, the case of profiteering of the name will also have a negative impact on the authority of the state because its leader is considered corruption.

Data (7) is a statement from President Joko Widodo. The consequences reflected in the President's verbal reaction above is on behalf of the President to ask for shares to PT Freeport will actually delegitimize the authority of state institutions, be it the presidential institution or other state institutions. Meanwhile, the data (8) is a verbal reaction from the former Chairman of Chairman of the Central Executive Muhammadiyah Ahmad Syafi Marif. Through these verbal reactions, communicating to the reader the impact that may be caused if HCC makes mistakes in decision making, namely the dissolution of dignity, dignity, and public trust to the House of Representatives.

In Kompas daily news texts there are also some elements of hope - things that may be caused or are the result of the events being preached. In other words, expectations contain predictions or diarrhea occurring in the future. Here are presented two elements of hope contained in the daily news texts Kompas.

9) "People still hope HCC members think clearly and uphold common sense "(news 5, sentence 2, paragraph 1).

10)Novanto's retreat is expected to further optimize DPR's performance (news 6, sentence 1 , paragraph 15$)$.

Elements of hope in the data (9 and 10) are expected expectations occur in the future. Expected expectations, namely: (1) HCC is expected to make 
decisions put forward ethical reason rather than political interests behind. Thus, the decision will be able to accommodate the expectations of the wider community; and (2) wants Setya Novanto to resign from his position to optimize the performance of the House of Representatives.

In addition to the elements of hope, in Kompas daily news texts there is also an element of evaluation - the views or opinions of journalists responding to the events being reported. One of the elements of evaluation contained in the news texts is:

11)During the lead of Novanto, in terms of achieving the legislation target, the House of Representatives has only approved two bills in the 2015 Priority National Legislation Program (Prolegnas) list and one Bill outside of Prolegnas Prioritas (news 6, sentence 2 para $15)$.

The evaluation element in the data (11), reinforced by the presence of a news context, is marked through word markers as long as the textual maker gives judgment, evaluation, and criticism of the performance of the House of Representatives as chaired by Setya Novanto, especially in achieving the legislation target of the House of Representatives.

\section{MICRO STRUCTURE OF KOMPAS DAILY NEWS TEXTS}

Analysis at the micro level begins with the discourse strategy at semantic, syntactic, stylistic, and rhetorical level. The strategy at the first semantic level is the use of detailed elements related to the control of the information a person displays. In Kompas daily news texts there are various detail elements. Below are presented two detailed elements as a representation of the whole daily Kompas news texts.

12) Until now, the President only requested four terms as a condition of PT FI contract extension. The four are related to PT FI royalties for Indonesia, divestment, smelter development, and Papua development. If not met, it will be the material of evaluation during the negotiation process of the contract (news 2, paragraph 27).

13) Yesterday, Court of Honor Council session led by Vice Chairman of Court of Honor Council from Golkar Party Faction Kahar Muzakir. Kahar and Novanto were once mentioned in the alleged bribery case of PON Riau 2012 (news 3 , paragraph 17).

The detailed elements in the data (12) have a positive impact on the party, namely President Jokowi. Through the details, the community will give positive association to the steps of the President. The meaning to be emphasized is the attitude of the President who requested four terms as a condition of contract extension with PT. The FI shows that the President prioritizes the public interest rather than personal or group interests. While, in the data (13), the emphasized meaning of the decipherment detail is on the existence of efforts from various parties to secure the case of profiteering on the name of President and Vice President. Efforts to secure the case of profiteering on the name, reinforced through the phrase: "Kahar and Novanto had together mentioned in the alleged bribery case of PON Riau 2012". With such writing patterns, the positions of Kahar Muzakir and Setya Novanto are presented negatively in the news text. Given, the text maker raises track record of both politicians who allegedly had been together involved in alleged bribery case PON Riau 2012.

The strategy at the next semantic level is the use of elements of intent - seeing information that benefits communicators will be described explicitly and clearly. One of the elements of the meaning contained in Kompas daily news texts is:

14) The shrinkage was related steps 30 members of Parliament who signed the statement the political stance of the Novanto movement urged to resign. They come from seven factions in the DPR. Three factions whose members did not sign the political stance are the Prosperous Justice Party Faction, Gerindra Party Faction, and Faction National Awakening Party (news 5, paragraph 17).

Through the intentional element in the data (14), the meaning to be emphasized in the text of the news is related to the steps taken by the 30 members of the People's Legislative Assembly who signed the statement of the political attitude of the movement urging Setya Novanto to resign from his position, in line with the expectations of the community. In the same paragraph, the news text also describes that there are also members of the council of three factions in the DPR, namely the Prosperous Justice Party faction, Gerindra Party Faction, and the National Awakening Party Faction which did not sign a statement of political stance. Through such decomposition, the implicit meaning to be conveyed is that the three factions represented by their members in the House of Representative do not listen to the aspirations and expectations of the public. The effect of the decomposition, of course, will negatively impact the image of the three fractions in front of the reader audience.

Strategyat the next semantic level is the use of prefixed element-statement used to support the meaning of a text. The conditional element is almost similar to the element of reasoning - it provides a rational basis, so that the text presented by the communicator seems correct and convincing. In Kompas daily news texts there are a number of preemptive elements. One of the elements of prejudice contained in the daily Kompas news texts, ie:

15)"This case can be dangerous because investor confidence is lost. In fact, Indonesia is inviting many investors. If the case is not explained, people no longer trust the government. If you do not believe in the President and Vice 
President, this country is damaged because its leader is considered corruption ", he said. (News 2; paragraphs 15).

Presupposition present in the data (15) is a direct quote from Vice President Jusuf Kalla. The above statement is an assumption or assumption because the reality has not happened yet. However, since this assumption is conveyed by the Vice President, the fact that has not been proven can be accepted by the reader's audience, that indeed the case of profiteering the name gives negative implications to Indonesian business world because it can cause loss of investor who will make investment.

In addition to the strategy at the semantic level, in Kompas daily news texts there is also a strategy on the syntactic level. The strategy at the first syntactic level is the use of passive sentences that are reflected through sentences:

16) "Novanto's retreat is expected to further optimize the House of Representative performance "(News 6, sentence 1, paragraph $15)$.

The meaning that emerged from the composition of this sentence is different, because the central position of the above sentence is Setya Novanto. Thus it gives glorification of error to Setya Novanto. That is, the message to be conveyed is the performance of House of Representative during Setya Novanto served as Chairman of the House has not shown satisfactory results. The strategy at the next syntactic level is the use of conditional coherence - characterized by the use of clause as explanatory. One of the uses of conditional coherence in the Kompas daily news texts, such as:

17) "The recording of the talks between Novanto, businessman Muhammad Riza Chalid and PT Freeport Indonesia (FI) President Director Maroef Sjamsoeddin on June 8, 2015, which among others allegedly contained a request for shares from PT FI by name of President Joko Widodo and Vice President Jusuf Kalla, according to Syafii Maarif, has been lit up indicating an ethical violation "(news 4, paragraph 3).

The meaning of the sentence in the data (17) will not change meaning if the clause "which among others is suspected to contain the request of shares of PT FI by taking the name of President Joko Widodo and Vice President Jusuf Kalla" is omitted in sentence. The clause serves as an explanation as well as reinforces that the recorded evidence allegedly contains the contents of the share request from PT FI. That is, the clause displayed in the sentence affirms that there is an ethical violation if it refers to the evidence of an existing recording.

The strategy at the next syntactic level is the use of the distinctive coherence - related to the statement of how the two events are to be distinguished. As in the following example:
18) Achievement of the House until the second year is lower than the achievement of the House of Representatives 2009-2014 period at the same time. Throughout 2010, the House of Representatives endorsed 8 RUUs from 70 RUUs which are a list of Prolegnas Prioritas 2010 (news 6, paragraph 17).

The use of the distinguishing coherence in the data (18) is characterized by the word compared. In this context, the author of the text compares with the achievement of the House of Representative for the period 2009-2014 with the achievement of the House of Representative of the period 2014-2019. The news text shows that the performance of House of Representative in the period of 2009-2014 especially in the second period is better than the achievement obtained by House of Representative period 2014-2019 during led by Setya Novanto. Given the use of the distinguishing coherence, the reader audience can provide an assessment of the performance of the House of Representatives during the leadership of Setya Novanto. The substance to be conveyed to the reader audience, namely the achievements obtained by the House of Representative period 2014-2019 inversely proportional to the achievements made by the House of Representative in the period 2009-2014.

The strategy at the next syntactic level is the use of pronouns - elements to manipulate language by creating an imaginative community, characterized by the use of our pronouns and our pronouns, like the following example:

19)"During this time, we are easy to forget and permissive against behaviors that harm the nation. However, now we can no longer be a forgetful nation, "he said (News 5, paragraph 13).

20) "This "Save Parliament" movement is a moral endorsement for our friends at HCC, which we believe strives to uphold a true code of ethics, "said House of Representative House member PAN fraction Teguh Juwarno. (News 5, paragraph 19).

The sentence in the data (19) is a direct quote from the statement submitted by the Secretary General of the Parisada Hindu Dharma Indonesia Ketut Purwarta. The use of pronoun we in the context of the sentence makes the attitude of the resource person to be a common attitude. That is, comments from sources quoted in the news represent the voice of all Indonesian society. Use of pronoun we strategically to foster mutual solidarity as it reduces the opissi between readers and resource persons. While, the use of pronoun we, on data (20), has implications for solidarity and eliminates the existing opisitions at the legislative level. That is, the comments conveyed by the informant in the news text, associate it as a common attitude of the legislature as a whole, who is still trying to enforce the correct code of ethics.

In addition to strategies at the syntactic level, 
in the news text there is also a strategy at the stylistic level. One of them is the use of diction or word choice. In the whole daily Kompas news texts there are a number of diction usages that aims to give a deep impression on the audience.

21)Publik Geram Ingin Dituntaskan second headline)

22) President Joko Widodo raised his anger when asked about the process at the HCC regarding his alleged profiteering on the case of PT Freeport Indonesia's share demand (news 3, paragraph 1).

23) Ahead of and during the examination of Novanto, there appeared a number of related reports of the existence of a number of political parties who agreed to secure Novanto in this case (News 3, sentence 1, paragraph 13).

24) "Among these are the keywords "Clean up the House" (News 4, sentence 3, paragraph 8).

25)A total of 30 members of the House of Representatives and several other members of the House of Representatives yesterday wore black bands saying "Save Parliament" during a plenary session and other activities in the DPR (news 5; paragraph 18).

26) This event also serves as a warning to all the people's representatives to never play the mandate of the people they represent (news 6, sentence 2, paragraph 1).

In political discourse (referring to data 21), the word public is often synonymous with the word "society." This plural pronoun is imaginary. The word growl shows anger or disappointment. By using a furious public phrase at data (21), the public anger mengasosiakianak that require cases of profiteering on the name of President and Vice President immediately resolved. Meanwhile, the professorial diction in the data (22), is defined as the use of power, authority or position illegally for the benefit of individuals or groups. In data (23), securing diction is not meant to be harmless or not violent, but can be interpreted as a political effort from a number of parties or political parties in the legislature to save Setya Novanto from the inclusion of the name of President and Vice President.

In data (24), the phrase clean up the House refers to efforts to restore the dignity and reputation of the House of Representatives. Meanwhile, black tape diction on data (25) contains a mourning message which is a symbol of resistance. Referring to the sentence above, the use of black ribbon diction is as a symbol of resistance from the legislative members who demanded justice in the House of Representatives. While, the word mandate (referring to data 26) is defined as a command or direction given by the people (people, associations, etc.) to someone (some) to be carried out in accordance with the will of the people. While the word folk can be interpreted as part of a country or an important element of a government. These two words are combined into the phrase mandate of the people (26) to give affirmation to the people's representatives to be responsible for the trust that has been given by the community in the legislature.

In addition to strategies at the stylistic level, in the text of the news there is also a strategy on the rhetorical level. One is the use of metaphors, like the following two examples:

27)I think this country has long since allowed its rulers to sneak around like thieves and there is no transparency "(News 2, sentence 1, paragraph 12).

28) Members of HCC need to remember, the voice of the people is the voice of God. "(Message 5 sentence 2, paragraph 14).

The use of phantom expression in the data (27) above is a metaphor. The phrase gives a negative connotation. Implicitly, the expression is also a reflection of corruption behavior that often occurs in Indonesia. Implicitly, the above sentence also gives criticisms of the state which is considered to be abandoning the abuse of power committed by the top brass or office holders. The use of metaphor in the context of the sentence above has a dialectical relationship with the case of profiteering of the President and Vice President involving one element of the House leadership, Setya Novanto. While the expression of the voice of the people is the voice of God to the data (28) implies that the voice of the people should be appreciated as the transmitter of the Divine will. Through the phrase, the message to be conveyed so that members of HCC always listen to the aspirations of the people, who expect justice in decision making cases of alleged violations of the code of ethics. Given, the news text negates that the voice of the people is representative of the voice of God. Therefore, it becomes morally necessary for the HCC members to follow the will of the people. Denying the aspirations and expectations of society is in accordance with against toward the will of God.

\section{SOCIAL COGNITION: MENTAL AWARENESS OF JOURNALISTS}

Analysis on the level of social cognition: the mental consciousness of journalists is limited to role schemes and event schemes. Given, these two dominant schemes are reflected in Kompas daily news texts.

\section{E. ROLE SCHEME}

Role scheme is related to how one view and describes the role and position one occupies in a society. In the context of this study reviewed is how journalists describe the role of positions of political leaders who dihadrikan in the news text, namely Chairman of the House Setya Novanto in his position in the community.

In general, people's representatives can be understood as people elected by the people through general elections to become representatives in parliament in order to fight for the aspirations and interests of the people. In the Big Indonesian Dictionary $(K B B I)$, representatives of the people are defined as persons who sit as members of the 


\section{RETORIKA: Jurnal Ilmu Bahasa , Vol. 4, No. 1 April 2018, Page 34}

representative body of the people; messenger of the people.

On the six headlines, the action of professing the names of the President and Vice President involving the Speaker of the House of Representatives Setya Novanto received a critical spotlight on the news. His position is marginalized in the news texts. Through its coverage, journalists provide association to the readers that the actions taken by Setya Novanto actually degrade the dignity of the President and delegitimize the authority of the House of Representatives as an institution that fights for the aspirations of the people.

Journalists are of the view that the strategic positions he carries should be enshrined for the benefit of society at large. Therefore, those who bear political responsibility should not forget or underestimate the ethical dimension of the principle of representation that council members take an important role in the fate of the people and strive to find a solution to every problem in society.

As a representative of the people, journalists hold that Setya Novanto should be responsible for the mandate given by the people, perform their functions and duties as people's representatives, and commit to fight for the aspirations of the people. Therefore, in carrying out its duties and functions as a member of legsilatif, he should display behavior based on good principles so as to be role models and figures for the community.

\section{F. EVENT SCHEME}

This scheme illustrates how journalists perceive the peritistiwa alleged profiteering of the President and Vice President to ask something (shares) to PT Freeport Indonesia associated with other events. Another event referred to here is how the relation of the case with the name of the two leaders of the country with the discourse of corruption.

The connection between the discourse of profiteering the name of President and Vice President with corruption can be observed from the use of words, phrases, or sentences in the news text. On the second story entitled: "Public Warming Want to Be Completed," in the news text there is the use of the word profiteer. The use of this profanity is reflected in the news terrace:

29) "Various petitions and expressions of pique appear in cyberspace. The contents illustrate public resentment and the desire of citizens to the case of politicians who allegedly took the name of the President and Vice President to ask for the shares of PT Freeport Indonesia to be resolved immediately "(paragraph 1$)$.

The word profitering on data (29) gives a negative connotation. The reason is, the word profitering is defined as: (1) trading (something) in an unnatural way and taking profit as much as possible, (2) seeking profits by unlawful means (e.g., by cheating or tricking), and (3) misusing (power, person's name, job title, etc.) to make a profit.
In the third news text entitled "President is Angry", it also finds how journalists link the discourse of profiteering on the two leaders of the country with corruption:

30. Yesterday, the HCC trial led by HCC Deputy Chairman of the Golkar Party Faction Kahar Muzakir. Kahar and Novanto were once mentioned in the alleged bribery case of PON Riau 2012 (paragraph 17).

Through this paragraph, journalists provide a historical background that relates to the alleged bribery case of Riau Sports Week (PON) in 2012 which involves Vice Chairman of HCC from Golkar Faction Kahar Muzakir and Chairman of the House of Representative, Setya Novanto.

\section{G. SOCIAL CONTEXT}

POWER AND ACCESS

According to Pilang (2004: 134), the media as a discourse will also discuss the language used therein, the underlying knowledge, and the forms of interests, and the power operating behind the language.

Language and power have close relationships. Language is used as a symbol to sustain power. The symbolization of power through language is reflected in the use of the pronoun, as in the following example:

31. The President added, "I'm okay to be called a crazy president, sarap, President Koppig (stubborn) is okay. But if it concerns the authority of profiteering (the name of the President) to ask for an 11 percent stake, this is what I do not want, do not want to. It's a matter of propriety. Fitishness, morality and it's a matter of state authority. Enough. "(News 3; paragraphs 5).

The use of my pronoun in data (31) can be interpreted as a symbol of power. The pronoun I give confirmation that the statement submitted above is an official statement from the President addressing the profiteering of his name. Through the use of my pronoun above attempts to imply the explicit meaning that no one can in the name of the President to gain profit. In view of the fact that acting on behalf of the President to ask for shares to PT Freeport of Indonesia undermines the dignity of the President as head of government and to the state.

Control over the above discourse can only be done by the dominant group, because according to van Dijk, as quoted by Eriyanto (2001: 12), the dominant group has more access to media than the non-dominant group. Thus, the dominant group has the opportunity to influence audience awareness $\mathrm{s}$ through its access to it.

The news discourse on the case of profiteering of the name of President and Vice President involving Chairman of the House Setya Novanto can be interpreted as a form of dominance from the executive over the legislature. Domination is 
produced by the granting of special access to one group compared to other groups. The executive group and the factions of political parties supporting the government in the legislature have greater access to Kompas daily than House Speaker Setya Novanto or factions of the government's opposition party. With access owned, executive groups and factions of political parties supporting the government have more opportunity to build public opinion. Thus, it has a greater chance to influence public awareness to follow the views or values of the dominant group.

In the six news that serve as the main data in the study, the substance of discourse developed by the dominant group, namely demanding the settlement of cases of profiteering of the President and Vice President to ask for shares to PT. Freeport through a code of ethics in the House of Representative. The settlement of this case is considered important because it concerns the good name of the presidential institution or state institution.

Giving more access to the executive and the factions of the party supporting the government in the legislature to submit statements or arguments regarding the case of profiteering the name of President and Vice President, is inseparable from the underlying political context. In the Presidential Election (Presidential Election) in 2014, it can not be denied that the Kompas daily is considered to support or support Jokowi and Jusuf Kalla, who at that time ran for President and Vice President. This allegation was expressed by Marah Sakti Siregar in the Journal of the Press Indonesia (2008: 23) which explains that several mainstream media groups - so far independent - through the content of the news clearly support Jokowi-JK. One of which is revealed is Group Kompas (founder and owner: Jacob Oetama et al.).

In addition, daily control of Kompas in controlling communicative events is reflected in the provision of more access to interfaith leaders such as: Former Chairman of Muhammadiyah Central Executive Ahmad Syafii Maarif, General Chairman of Nahdatul Ulama KH Said Aqil Siroj, Chairman General Muhammadiyah Central Leaders Haedar Nashir, Chairman of the Conference of Indonesian Church Guardians (KWI) Mgr. Ignatius Suharyo, Chairman of the Communion of Churches in Indonesia Pastor Henriette T. Hutabarat, Coordinator of Buddhist Council of Indonesian Buddhist Representative Rusli Tan, General Secretary of the Parisada Hindu Dharma Indonesia Ketut Purwarta, Chairman of the Confucian High Council of Religion Indonesia Unung Sedana.

The substance of the discourse is developed by interfaith leaders as follows. First, if HCC and HCC are still willing to listen to the people give severe sanctions to Setya Novanto for having committed severe violations. Second, HCC will be delegitimated when HCC overrides honesty and integrity. Thirdly, the tape played in the hearing indicates that it is not the general welfare that is fought for but the interests of the individual or group. Fourth, ask the community to provide social sanctions for them (members of the legislature) who eliminates ethical violations in this case. One of them no longer trusts them as representatives of the people. And Fifth, HCC members need to remember, the voice of the people is the voice of God.

More access given by Kompas daily was not without reason, but was suspended because of the similarity of values, views or ideologies between religious leaders and the values held by Kompas daily by institution, namely Pancasila. With such access, it is easier for interfaith leaders to construct discourse constructs that corner Setya Novanto for his actions, or the HCC, which is considered to be trying to secure the case of profiteering the name. The substance of discourse developed by the interfaith leaders, of course, has a strong influence on the wider Indonesian society. A very strong Indonesian society with religiosity will be easy to believe in the opinions expressed by interfaith leaders. Indirectly, the substance spoken by interfaith leaders will no doubt be the basis of truth in front of audiences.

\section{H. IDEOLOGY}

Critical discourse analysis sees a hidden ideology in language usage. Ideology is a central study in critical discourse analysis. This is according to Eriyanto (2001: 13) because the text, the conversation, and others is a form of ideological practice or reflection of a particular ideology. The ideology that is reflected in Kompas daily news texts is Pancasila.

In relation to the media, ideology becomes the basic view and principles held by the media in positioning the relevant media institutions against the events to be reported. Ideology ultimately determines a group's vision or vision of reality. Based on the analysis of Kompas daily news, the reflection of Pancasila ideology is reflected through the use of folk words or phrases such as: popular voice, people's mandate, people's power and people's conscience.

The reflection of the ideology of Pancasila implied by word or phrase in Kompas daily texts is closely related to the vision and spirit of the media institutionally. In the book entitled Gratitude End: Jakob Oetama Steps compiled by Sularto (2015: 28), Jakob Oetama who is one of the founders of Kompas writes the attitude and manner of Kompas since its inception in the Head of Plan.

32) Our compasses are Pancasila, Manipol and God's grace. The bearer of the conscience of the people, because the Manipol taught "the essence of the Indonesian revolution is the same as. Social human consciousness ". The conscience that desires social welfare with. Dignity and social. Prosperity demikain that call jg. God mandated. But the realization is accompanied by struggle, because humans are blessed also free will. There are objective requirements too. It is needed to realize the demands of hatinurani it is God's freedom, justice, and grace. Since every form of 
oppression and exploitation disowns the objective conditions, the conscience opposes those forms of oppression (Kompas, 28 June 1965).

In the context of media (print and electronic), the editorial is the voice of opinion of the media institution and the personality of the media concerned. Thus, through the above editorial, it can be concluded that Pancasila became the vision and spirit of the Kompas institutionally then actualized in the work of journalism.

\section{III.CONCLUSION}

Based on the discussion that has been described before, some of the conclusions of this study are as follows:

First, at the level of the structure of the text, especially in the level of macro structure, the global meaning of the whole daily Kompas texts is to demand the settlement of the case of profiteering on the name of the President and the Vice President. The macro structure is then supported by a superstructure that includes: summary (title, news terrace), main events, context and history, verbal reactions, expectations and evaluation. The above superstructure is then reinforced by the microstructure of the news texts, which include detailed elements, meaning elements, presuppositions, sentence forms, conditional coherence, distinctive coherence, pronouns, lexicon and metaphorical usage. The use of lexicon is dominant in the news text. The use of the lexicon as part of Kompas daily strategy of discourse is to support news topics.

Second, social cognition: the mental consciousness of text-producing journalists is explored through role schemes and event schemes. Through the role scheme, journalists believe that the strategic positions held by Setya Novanto should be enshrined for the benefit of the people and strive to find solutions to every social problem in society. While through the scheme of events, described that the act of profiteering the name was associated with the discourse of corruption. It is observed from lexical choices or sentences in the news text.

Third, the social context contained in the news texts is examined through aspects of power and access. The news discourse on the case of profiteering on the name of the President and Vice President to ask something (shares) to PT Freeport Indonesia is a form of domination. The practice of power is symbolized through language, especially through the use of pronouns. In addition, dominance is produced by giving special access to one group compared to other groups. With this greater access, it is easier for the executive group or the factions of political parties supporting the government in the legislature, as well as interfaith leaders to get their views publicly.

Fourth, the ideology which is reflected in Kompas daily news texts is Pancasila. The reflection of the ideology of Pancasila is implied by the word people or phrase the voice of the people, the mandate of the people, the power of the people, and the conscience of the people. The reflection of Pancasila ideology in Kompas daily news texts is closely related to the vision and spirit of the media institutionally.

\section{AKNOWLEDGEMENT}

This research can be completed thanks to the help, support, and cooperation of various parties. Therefore, on this occasion the author would like to convey profuse thanks to prof. Dr. I Nyoman Kardana, M. Hum as the supervisor I and Dr. I Wayan Budiarta, S.S, M. Hum as lecturer II. The authors also extend their gratitude to the Chairman of Master Program of Linguistics, Dr. Ni Wayan Kasni, M.Hum, who always educates and guides the author during his study in Linguistics Master Program, Graduate Program of University of Warmadewa.

\section{REFERENCES}

Arifin. 2012. Modul Teori dan Aplikasi Analisis Wacana: Program Studi Pendidikan Bahasa. Singaraja: Undiksha.

Badara, A. (2012). Analisis Wacana: Teori, Metode, dan Penerapannya pada Wacana Media.

Dharma, Yoce Aliah. 2009. Analisis Wacana Kritis. Bandung: YRAMA WIDYA.

Effendy, Onong Uchjana 1993. Ilmu, Teori dan Filsafat Komunikasi. Bandung: PT. Rosdakarya.

Eriyanto. 2001. Analisis Wacana: Pengantar Analisis Teks Media. Yogyakarta: LKiS.

Fairclough, Norman 2003. Relasi Bahasa, Kekuasaan, dan Ideologi. Terjemahan Indah Rohmani. Malang: Boyan Publishing.

Halliday, M A K., Hasan, R. (1992). Bahasa, Konteks, dan Teks: Aspek-Aspek Bahasa Dalam Pandangan Semiotik Sosial. Yogyakarta: Gadjah Mada University Press.

Mbete, A. M. (2013). Dinamika Bahasa Media. Denpasar: Udayana University Press.

Moleong, Lexi J. 2014. Metodologi Penelitian Kualitatif. Bandung: PT. Remaja Rosdakarya.

Pastika, I Wayan (editor). 2013. Dinamika Bahasa Media: Televisi, Internet, dan Surat Kabar. Denpasar: Udayana University Press.

Piliang, Y. A. (2004). Posrealitas: Realitas Kebudayaandalam Era Post metafisika. Yogyakarta: Jalasutra.

Rokhman, Fathur \& Surahmat. 2016. Politik Bahasa Penguasa. Jakarta: PT. Kompas Media Nusantara.

Sobur, A. (201). Analisis Teks Media: suatu pengantar untuk analisasi wancana, analisis, semiotik, dan analisis framing. Bandung: PT. Remaja Rosdakarya.

Sugiya, Aritasius., Ratnawati, S. (2016). Buku Pintar Kompas 2015. Jakarta: PT. Kompas Media 


\section{RETORIKA: Jurnal Ilmu Bahasa , Vol. 4, No. 1 April 2018, Page 37}

Nusantara.

Sudibiyo, Agus. (editor) Pers dan Suksesi Kepemimpinan Nasional. Jurnal Pers Indonesia Edisi 3, No.8 Oktober 2015. Jakarta: PWI Pusat.

Sugiya, Aritasius \& Sintha Ratnawati (editor). 2016. Buku Pintar Kompas 2015. Jakarta: PT. Kompas Media Nusantara.

Sularto. 2015. Jejak langkah Jacob Oetama. Jakarta: PT. Kompas Media Nusantara

Suryawati, I. (2011). Jurnalistik Suatu Pengantar Teori dan Praktik. Bogor: Ghalia Indonesia.

Titsher, Stefan dkk. 2009. Metode Analisis Teks dan Wacana. Terjemahan Gazali, dkk. (editor) Abdul Syukur Ibrahim. Yogyakarta: PustakaPelajar.

Todo, Marianus F. L. 2017. Analisis Wacana Kritis Pemberitaan Surat Kabar Harian Kompas Tentang Pencatutan Nama Presiden Jokowi dan Wakil Presiden Jusuf Kalla (tesis). Denpasar: Universitas Warmadewa.

Tompshon, John. B. 2014. Analisis Ideologi Dunia. Terjemahan Haqqul Yaqin. Yogyakarta: IRCi.SoD.

Utama, I Dewa Gede Budi. 2015. Analisis Wacana Kritis Berita tentang Rencana Tata Ruang Wilayah Provinsi (RTRWP) Bali (tesis). Denpasar: Universitas Udayana.

Van Dijk, T. A. (1985). Structure of News in The Press. De Gruyter, 69-93.

Van Dijk, T. A. (1995). Power and The News Media. Retrieved from http:// www.discourses.org/download/articles/
1985. Structure of News in The Press. Dalam van Dijk, Teun A. (ed.) Discourse and Communication. Berlin: De Gruyter. p. 6993. Situs: (http://www.discourses.org/ download/articles/) diakses pada tanggal19 Agustus 2016.

1986. News Schemata. Dalam S. Greenbaum \& Copper (ed.) Studying Writing. Linguistic approaches. Beverly Hills, CA: Sage. p. 155186 Situs: (http://www.discourses.org/ download/articles/) diakses pada tanggal 19 Agustus 2016.

1989. Social Cognition and Discourse. Dalam H. Giles \& R.P. Robinson (ed.) Handbook of social psychology and language. Chichester: Wiley. p. 163183.Situs: (http://www.discourses.org/ download/articles/) diakses pada19 Agustus 2016.

2001. Multidisciplinary CDA: A Plea for Diversity. Dalam Ruth Wodak dan Michael Meyer, ed. Methods of Critical Discourse Analysis. London: SAGE Publications p. 95115.

Wodak, Ruth. 2001. What CDA is about - a summary of its history, important concepts and its developments dalam Ruth Wodak dan Michael Meyer, ed. Methods of Critical Discourse Analysis. London: SAGE Publications p. 1-12 